Not by Bread Alone 
This page intentionally left blank 


\section{Not by Bread Alone}

Social Support in the New Russia

Melissa L. Caldwell 
University of California Press

Berkeley and Los Angeles, California

University of California Press, Ltd.

London, England

(C) 2004 by the Regents of the University of California

Chapter 6 was adapted from an article previously published as "The Social Economy of Food Poverty in Russia," in Culture and Economy: Contemporary Perspectives, edited by Ullrich Kockel (Aldershot, England: Ashgate Publishing [2002]).

All photographs by the author, William H. Caldwell, and Sandra L. Caldwell.

Library of Congress Cataloging-in-Publication Data

Caldwell, Melissa L.

Not by bread alone : social support in the new Russia / Melissa L. Caldwell.

p. $\mathrm{cm}$.

Includes bibliographical references and index.

ISBN 0-520-23875-3 (cloth: alk. paper) - ISBN o-520-23876-I (pbk.: alk. paper)

I. Soup kitchens-Russia (Federation)-Moscow. 2. Social networksRussia (Federation). 3. Food relief-Russia (Federation). 4. PoorRussia (Federation). 5. Russia (Federation)-Social conditions-I99I-. I. Title.

HV696.S6 C 352004 $362.5^{\prime} 83-\mathrm{dc} 2 \mathrm{I}$ 2003014268

Manufactured in the United States of America

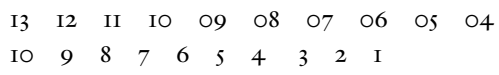

The paper used in this publication meets the minimum requirements of ANSI/NISO Z39.48-I992 (R 1997) (Permanence of Paper). 